\title{
PKM Pengelolaan Sampah Metode Takakura di Kelurahan Dukuh Pakis Surabaya
}

\author{
Novia Ariyanti ${ }^{1}$, Fitri Nur Latifah ${ }^{2}$, Bayu Hari Prasojo ${ }^{3}$ \\ Universitas Muhammadiyah Sidoarjo \\ ${ }^{1}$ e-mail: noviaariyanti@umsida.ac.id; Hp. 083830198646 \\ ${ }^{2}$ e-mail: fitrinurlatifah@umsida.ac.id; Hp. 082141651000 \\ ${ }^{3}$ e-mail: bayuhariprasojo@umsida.ac.id; Hp. 085607221081
}

\begin{abstract}
Abstrak
Tujuan program pengabdian ini adalah meningkatkan pengetahuan dan memberdayakan masyarakat tentang pengolahan sampah organik rumah tangga dengan metode Takakura. Mitra kegiatan ini adalah ibu-ibu PKK RW 01 Kelurahan Dukuh Pakis. Permasalahan yang dihadapi oleh mitra adalah: 1)masih minimnya pengetahuan tentang pengolahan sampah organik, 2)sampah organik rumah tangga yang melimpah, dan 3 ) kurangnya kepedulian masyarakat tentang manfaat dari pengolahan sampah organik. Metode kegiatan adalah ceramah dan demonstrasi disertai tanya jawab. Metode ceramah diperlukan untuk menjelaskan sistem pengelolaan sampah perkotaan, bagaimana mengelola dan mengolah sampah rumah tangga berupa workshop pengolahan sampah organik dengan metode Takakura. Metode demonstrasi untuk menunjukkan proses kerja pengolahan sampah organik rumah tangga dengan metode Takakura, sedangkan tanya jawab untuk memberikan kesempatan para peserta untuk mengatasi kendala yang mungkin dihadapi. Hasil program ini adalah adanya peningkatan pemahaman dan peningkatan kepedulian masyarakat mitra tentang pentingnya pengolahan sampah organik. Dengan adanya program pengabdian ini peningkatan pemahaman dan peningkatan kepedulian masyarakat mitra tentang pentingnya pengolahan sampah organik meningkat. Berkurangnya sampah organik di lingkungan RW 01 Kelurahan Dukuh Pakis menciptakan lingkungan yang bersih dan sehat serta dapat menghasilkan pupuk organik secara mandiri.
\end{abstract}

Kata kunci: Sampah organik, metode Takakura, pengelolaan sampah, pelatihan

\section{Abstract}

The purpose of this service program is to increase knowledge and empower the community about processing household organic waste by the Takakura method. The partners of this activity are PKK RW 01 women, Dukuh Pakis Village. The problems faced by partners are: 1) lack of knowledge about processing organic waste, 2) abundant household organic waste, and 3) lack of public awareness about the benefits of processing organic waste. The method of activity is lecture and demonstration with questions and answers. The lecture method is needed to explain the urban waste management system, how to manage and process household waste in the form of a workshop on processing organic waste using the Takakura method. Demonstration method to show the process of processing household organic waste by the Takakura method, while question and answer to provide the opportunity for participants to overcome obstacles that may be faced. The results of this program are an increase in understanding and increasing awareness of partner communities about the importance of processing organic waste. With this service program, the understanding and awareness of the partner community about the importance of processing organic waste increases. The reduction of organic waste in the environment of RW 01 Dukuh Pakis Village creates a clean and healthy environment and can produce organic fertilizer independently.

Keywords: Organic waste, Takakura method, waste management, training

\section{PENDAHULUAN}

Surabaya adalah salah satu kota metropolitan di Indonesia yang beriklim tropis dengan suhu udara yang panas ketika musim kemarau. Polusi udara menambah masalah bagi kota Surabaya yang merupakan kota besar kedua setelah Jakarta. Untuk itu pemerintah Surabaya mulai tahun 2005 mencanangkan program Green and Clean. Program Green and Clean adalah suatu program yang bertujuan menciptakan kondisi 
lingkungan yang bersih, hijau dan sehat untuk dihuni oleh masyarakat yang dicapai melalui terselenggaranya beberapa kegiatan yang menitikberatkan pada pengolahan sampah dan penghijauan. Sehingga dapat dikatakan program Surabaya Green and Clean ini adalah upaya pemerintah Surabaya untuk mengatasi permasalahan lingkungan yang sering terjadi di Surabaya. Salah satu permasalahan lingkungan yang memerlukan penanganan serius adalah pencemaran lingkungan yang disebabkan oleh adanya sampah.

Berdasarkan Undang-Undang No. 18 Tahun 2008, sampah adalah sisa kegiatan sehari-hari manusia dan atau proses alam yang berbentuk padat. Jenis sampah dibagi tiga yaitu sampah organik, sampah anorganik dan sampah berbahaya (Kuncoro Sejati, 2009). Bertambahnya jumlah penduduk di suatu wilayah mengakibatkan bertambah pula sampah yang dihasilkan. Salah satunya adalah sampah rumah tangga yang merupakan penyumbang terbesar dalam peningkatan jumlah sampah di suatu wilayah. Adanya sampah rumah tangga di suatu wilayah ini tidak bisa dihindarkan. Hal ini dikarenakan pengelolaan sampah yang masih didominasi dengan sistem pengumpulan sampah, pengangkutan sampah dan pembuangan ke Tempat Pemrosesan Akhir (TPA). Penanganan sampah yang kurang optimal dapat menyebabkan permasalahan lingkungan, seperti banjir, timbulnya penyakit, sanitasi lingkungan yang buruk dan mempercepat terjadinya pemanasan global. Untuk itu diperlukan suatu komitmen bersama dalam pengelolaan dan pengolahan sampah sehingga tercipta lingkungan yang bersih, sehat dan asri.

Untuk pengelolaan sampah anorganik di Kelurahan Dukuh Pakis RW 01 sudah berjalan dengan adanya bank sampah yang dikelola oleh ibu-ibu PKK. Tetapi, pengelolaan sampah organik di Kelurahan Dukuh Pakis RW 01 masih kurang mendapat perhatian yang serius dari masyarakat sekitar. Hal ini dikarenakan kurangnya pengetahuan dan tidak memiliki sarana prasarana untuk pengelolaan sampah organik. Peran masyarakat sangat diperlukan dalam pengelolaan sampah tidak hanya dalam membuang sampah pada tempatnya dan mengumpulkan sampah anorganik tetapi juga diharapkan pengolahan sampah organik yang dapat memberikan manfaat kembali bagi masyarakat sekitar.

Berdasarkan permasalahan tersebut sebagai salah satu bentuk tanggung jawab dosen dalam melaksanakan tridarma perguruan tinggi yaitu melakukan pengabdian pada masyarakat berupa pelatihan dan sosialisasi pengolahan sampah organik skala rumah tangga dengan mengunakan metode Takakura. Dengan pelatihan ini diharapkan sampah organik rumah tangga dapat dijadikan pupuk kompos yang dapat menyuburkan tanaman bagi masyarakat sekitar.

Kegiatan ini tidak dapat berjalan dengan lancar tanpa peran masyarakat terutama ibu-ibu karena salah satu perannya adalah sebagai ibu rumah tangga. Pelatihan pengolahan sampah organik pada ibu-ibu PKK Kelurahan Dukuh Pakis ini diharapkan dapat ditularkan ilmunya kepada ibu-ibu yang lain sehingga dapat terwujud lingkungan yang bersih, tidak perlu membeli pupuk karena sudah tersedia dan tanaman sekitar menjadi subur. Tujuan dari kegiatan ini adalah meningkatkan pengetahuan serta kesadaran masyarakat tentang pentingnya pengolahan sampah organik, meningkatkan pengetahuan tentang pengolahan sampah metode Takakura, memberdayakan dan memfasilitasi masyarakat dalam pengolahan sampah organik

\section{BAHAN DAN METODE}

Metode kegiatan pengabdian yang digunakan adalah metode ceramah. Sasaran kegiatan ini adalah ibu-ibu PKK RW 01 di Kelurahaan Dukuh Pakis sebanyak 15 orang perwakilan dari 5 RT. Metode ceramah ini digunakan untuk menyampaikan informasi mengenai lingkungan hidup, klasifikasi sampah, peran serta ibu-ibu rumah tangga dalam menjaga lingkungan hidup dan pengolahan sampah organik dengan metode Takakura dan metode demostrasi untuk menunjukkan proses kerja sehingga peserta pelatihan dapat 
dengan mudah mengerti. Demonstrasi dilakukan oleh dosen tim pengabdian masyarakat sebagai nara sumber. Hal ini diharapkan peserta pelatihan dapat melakukan simulasi tentang pengolahan sampah organik dengan metode Takakura sesuai dengan petunjuk yang telah diberikan.

\section{HASIL}

Hasil program pengabdian ini adalah menunjukkan adanya antusias masyarakat mitra dalam pengelolaan sampah organik. Masyarakat dapat menghasilkan pupuk organik secara mandiri. Melalui sosialisasi dan pelatihan ini, masyarakat menyadari akan pentingnya pengelolaan sampah organik rumah tangga demi terciptanya lingkungan yang sehat dan bersih.
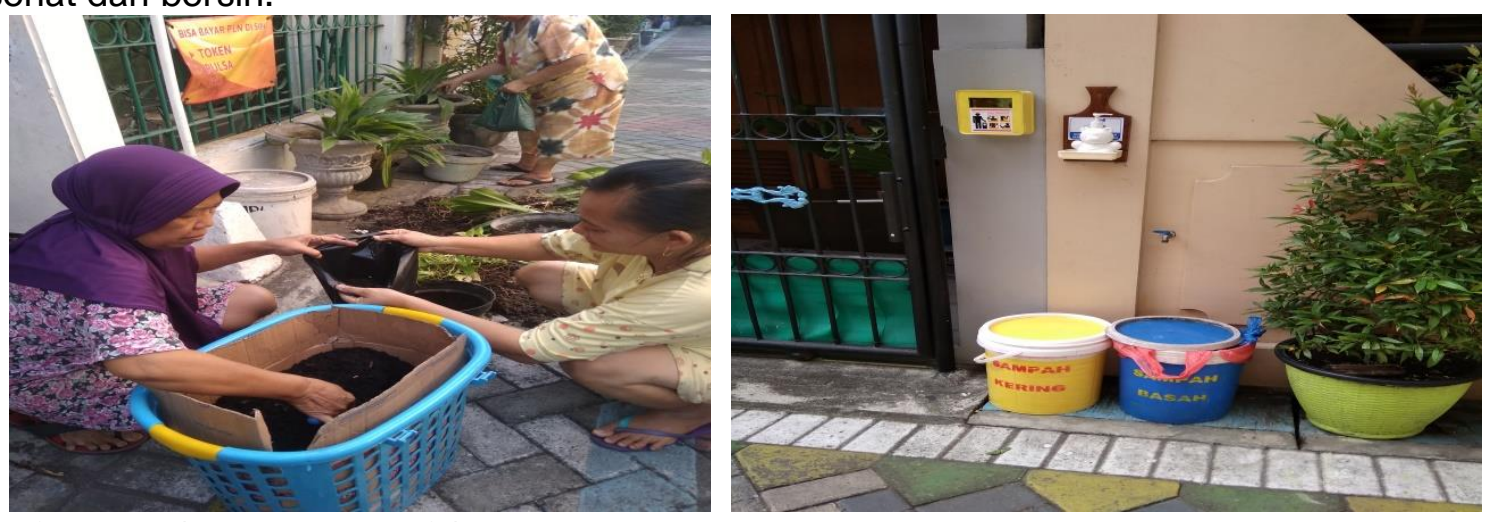

Gambar 1. Ibu- ibu RW 01 memanen pupuk organik dan tersedianya dua jenis tempat sampah

Masyarakat dapat menghasilkan pupuk organik secara mandiri. Peningkatan pemahaman dan peningkatan kepedulian masyarakat mitra tentang pentingnya pengolahan sampah organik ditunjukkan dengan berkurangnya sampah organik secara signifikan dan tersedianya dua jenis tempat sampah kering (anorganik) dan sampah basah (organik) di lingkungan RW 01. Masyarakat dapat menghasilkan pupuk organik secara mandiri. Dengan danya program pengabdian ini peningkatan pemahaman dan peningkatan kepedulian masyarakat mitra tentang pentingnya pengolahan sampah organik meningkat.

\section{PEMBAHASAN}

Antusias masyarakat mitra dalam sosialisasi dan pelatihan pengelolaan sampah organik dapat terlihat pada ibu-ibu yang hadir sesuai dengan undangan serta bersemangat untuk mengajukan pertanyaan mengenai bagian-bagian dari keranjang Takakura. Ibu-ibu juga melakukan praktek langsung tentang tata cara penggunaan keranjang Takakura.

\section{KESIMPULAN DAN SARAN}

Dengan adanya program pengabdian ini peningkatan pemahaman dan peningkatan kepedulian masyarakat mitra tentang pentingnya pengolahan sampah organik meningkat. Berkurangnya sampah organik di lingkungan RW 01 Kelurahan Dukuh Pakis menciptakan lingkungan yang bersih dan sehat serta dapat menghasilkan pupuk organik secara mandiri. Program pengabdian ini berharap dapat berlanjut dalam pemanfaatan pupuk organik sebagai media untuk menananam sayuran organik. Sehingga masyarakat dapat menghasilkan sayuran organik secara mandiri.

\section{UCAPAN TERIMA KASIH}

Terima kasih kami ucapkan kepada Universitas Muhammadiyah Sidoarjo yang telah memberikan bantuan dana dan dukungan, ibu-ibu PKK RW 01 Kelurahan Dukuh Pakis 
Surabaya serta kepada M. Koko Ardiansyah sebagai nara sumber dari Fakultas Pertanian Universitas Muhammadiyah Sidoarjo. Semoga pelaksanaan program pengabdian ini dapat memberikan manfaat yang lebih kepada masyarakat luas.

\section{DAFTAR PUSTAKA}

Anonim. 2008. Penanganan dan Pengelolaan Sampah. Jakarta: Penebar Swadaya. Damanhuri, E, dkk. 2004. Diktat Kuliah Pengelolaan Sampah. Edisi Semester 1 2004/2005.

Bandung: ITB

Sofian. 2009. Sukses Membuat Kompos dari Sampah., Jakarta: PT. Agromedia Pustaka. Undang-Undang Republik Indonesia Nomor 18 Tahun 2008 tentang Pengelolaan Sampah. 


\section{LAMPIRAN}
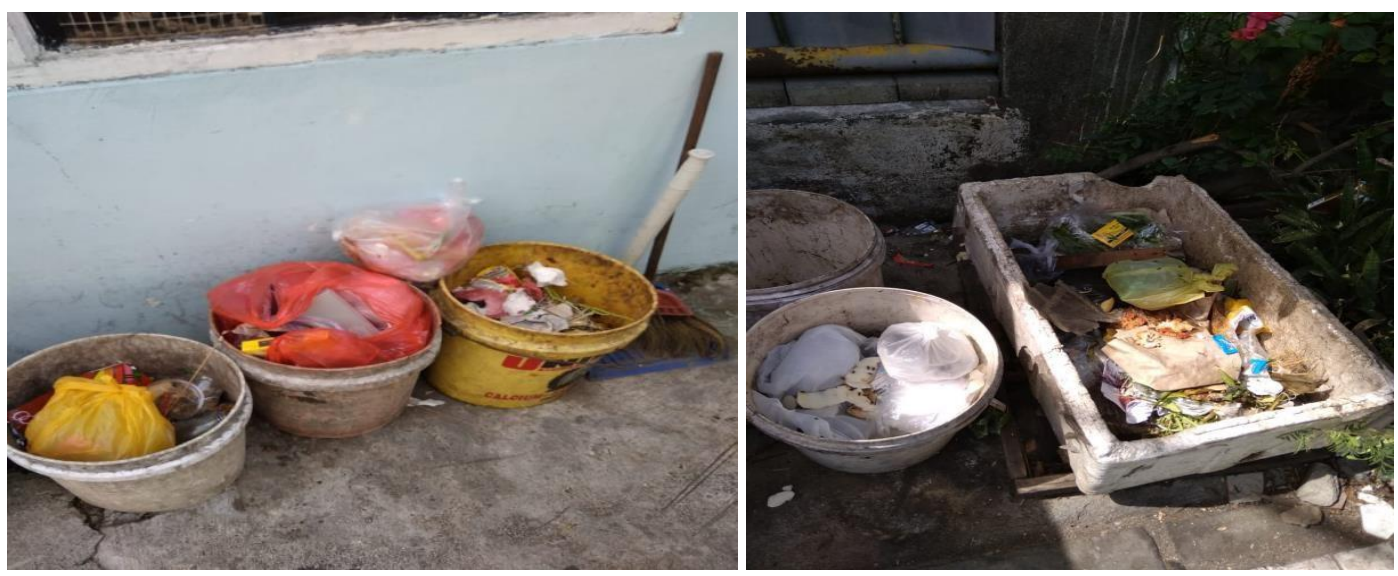

Gambar 2. Sampah organik yang menumpuk di RW 01 Kelurahan Dukuh Pakis Surabaya
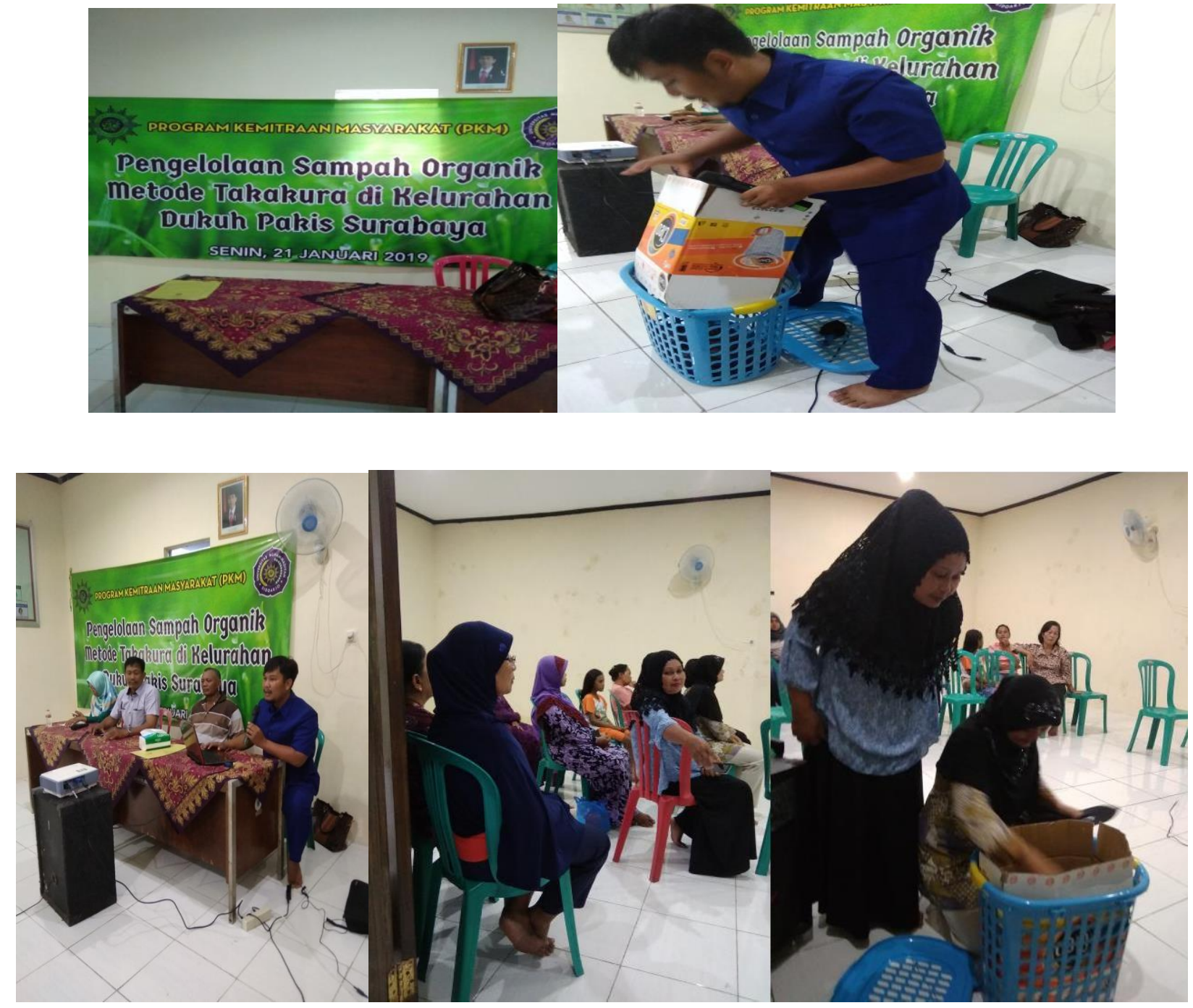

Gambar 3. Sosialisasi dan pelatihan pengelolaan sampah organik metode Takakura 


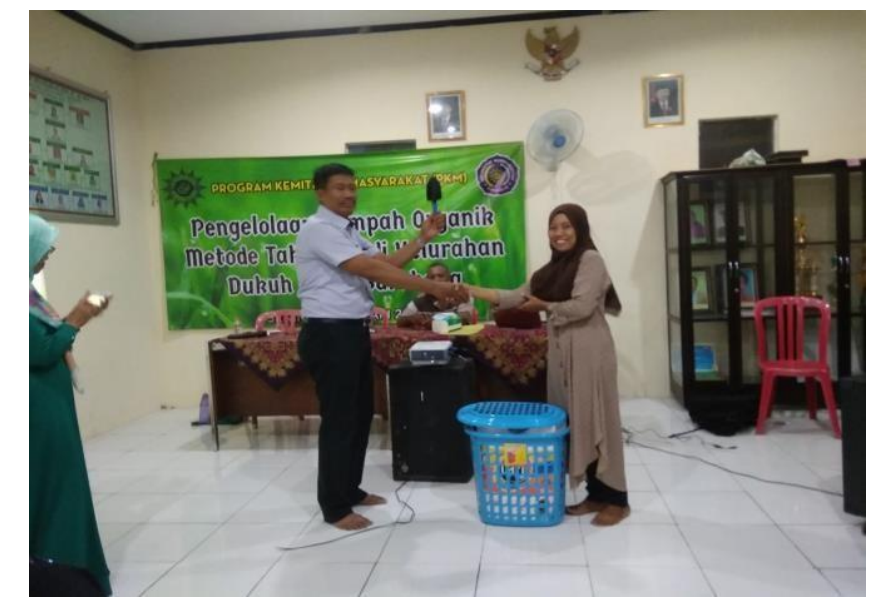

Gambar 4. Penyerahan simbolis keranjang Takakura kepada Ketua RW 01 Kelurahan Dukuh Pakis
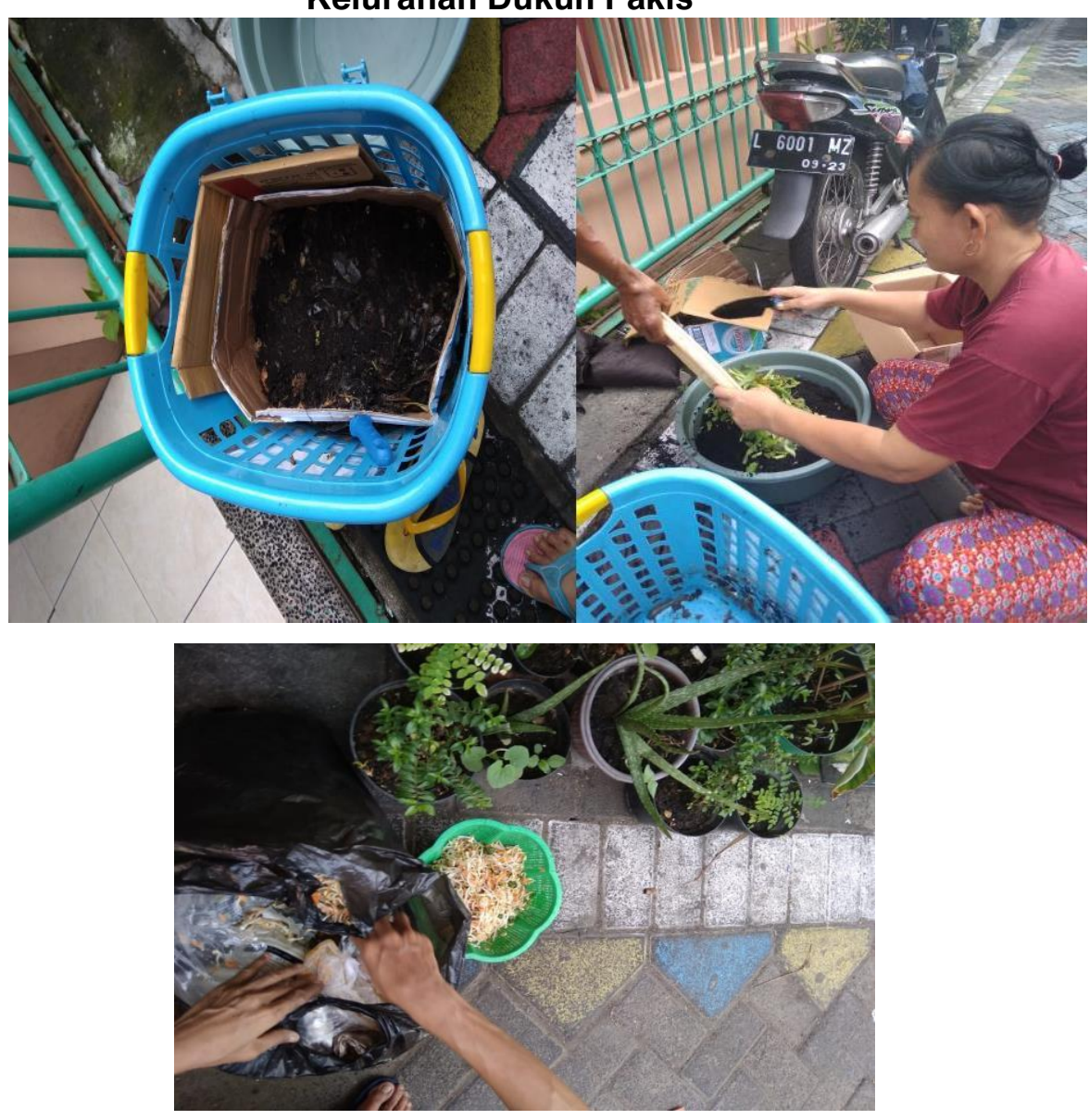

Gambar 5. Pengelolaan samapah organik metode Takakura 